\title{
Sustainability of Community Based Water Projects: Dynamics of Actors' Power Relations
}

\author{
Rehema Kilonzo $^{1} \&$ Victor George ${ }^{1}$ \\ ${ }^{1}$ Department of Development Studies, The University of Dodoma, Dodoma, Tanzania \\ Correspondence: Rehema Kilonzo, Department of Development Studies. The University of Dodoma, P.O. Box \\ 395, Dodoma, Tanzania. E-mail: kilonzo_rehema@yahoo.com
}

Received: August 2, 2017

Accepted: September 18, 2017

Online Published: November 29, 2017

doi:10.5539/jsd.v10n6p79

URL: https://doi.org/10.5539/jsd.v10n6p79

\begin{abstract}
Sustainability of Community Based Water Projects (CBWP) in Central Tanzania was examined. Actors' power was hypothesized to influence sustainability of the CBWP. Power was analyzed from two aspects; power structures and power relations. A cross-sectional design was adopted, which allowed data to be collected once at a point. A multi-stage sampling technique was used to get the study sample. Stratified random sampling was employed to get 30 CBWP for the study and simple random sampling was used for obtaining 390 households. Purposive sampling was also employed to obtain the key informants for in-depth interviews and Focus Group Discussions Quantitative data obtained were processed and analyzed using Statistical Package for Social Sciences (SPSS 16v.) while qualitative data were transcribed and content analysis was employed in analyzing them. In examining the power structure the study shows that institutions and empowerment have significant correlation with sustainability status of the CBWP. The study also shows that global and national actors have high influence/power in effecting the CBWP critical activities. The local actors are perceived to be powerless; however, the study indicates importance of recognizing them because their position as powerless actors may limit their participation in the CBWP and thus jeopardizing the chances of yielding sustainable CBWP.
\end{abstract}

Keywords: sustainability, actors, power structure, power relations

\section{Introduction}

Governments and development agencies have been heftily investing in water projects, however, many projects fail or lack sustainability component (Hodgkin, 1994, Baumann, 2005, Water Aid, 2006). Providing water security is a key dimension of poverty reduction in developing countries (GTZ, 2001). It is estimated that $35 \%$ of all rural water supplies in Sub-Saharan Africa are not functioning (Baumann, 2005; UNICEF and WHO, 2005). Different studies have been conducted in different areas to establish reasons for failure of development projects. For example, Sara and Katz (1997) and Khwaja (2001) found that community participation correlates with sustainability and if the participation is not considered then one should expect challenges. Furthermore, institutional participation is also vital in assuring sustainability of water project (Kleemeier, 2000). Harvey and Reed (2004) associates un-sustainability of the water projects with poor maintenance and operations of the systems.

Governments and development agencies have been heftily investing in water projects, however, many projects fail or lack sustainability component (Hodgkin, 1994; Baumann, 2005; Water Aid, 2006). Providing water security is a key dimension of poverty reduction in developing countries (GTZ, 2001). It is estimated that $35 \%$ of all rural water supplies in Sub-Saharan Africa are not functioning (Baumann, 2005; UNICEF and WHO, 2005). Different studies, which were conducted in different areas to establish reasons for failure of development projects, revealed that community participation correlates with sustainability and participation (Sara and Katz 1997; Khwaja 2001). Furthermore, institutional participation is a vital in assuring sustainability of water project (Kleemeier, 2000). Harvey and Reed (2004) associates un-sustainability of the water projects with poor maintenance and operations of the systems. In practice, the pursuit of sustainability is fundamentally a local effort because every community has different social, economic, and environmental needs and concerns. The question of sustainability includes actors at local national and global levels, and the development process. The actors of water projects include institutions such as; national, regional agencies, private sector, local community and the external institutions. A thorough understanding of actors and their interest for participation is critical to 
success of such projects (Long, 2004).

\subsection{Development Process, Design and Participation}

The key development process includes design and participation (Kamanzi, 2007). Project actors at all levels are expected to assist the project starting from the design. Design should be produced with many inputs from involved actors. Actors' requirements should be directly addressed from the project design (Hodgkin, 1994). When these project actors meet in a locality they both have different interests, power and perspective on the projects (Kamanzi, 2007; Kilonzo, 2017). Analytically, the exercise of power from global actors and the possibility of resistance from local actors establish a limit of participation in the projects (Scott, 2001). Since community based water projects depend much on participation of all actors, in which there should be a harmonized environment where all categories of actors should be satisfied in terms of power wielding.

The concept of power is multi-dimensional ranging from the notion of command of force as advocated by Weber (1964) to the discourse of power relations, empowerment and poverty (Foucault, 1980). Power is embedded in the relationships that shape how one person or organization has more control over something than others (Alsop, 2004). The central argument has been on the influence of an individual or group over others, which could elicit a change in behavior or social orientations as an effect of such practice. Many studies on sustainability of community based water projects have not included power as one aspect that could influence sustainability.

In this article power is analyzed from two perspectives including: power structure and power relation. The idea of power structure can be analyzed at three levels: governance, informality and empowerment (Lewis and Hossain, 2008). The first level involves formal institutions of governance operating at central and local levels. The approach looks at the way in which institutions operate, while challenging them to improve their effectiveness. The focal point of the second level is the role of informal relationship within the power structure. The 'net' study conducted by Bridging Resources Across Communities (BRAC's) (1983), form a landmark in characterizing informal exclusionary processes operating within the power structure at the local level. The third level in the analysis of power structure is empowerment; it focuses on the community organization, gender, civil society and NGOs (Wood, 1992 as quoted by Lewis and Hossain, 2008). This level focuses on how to increase power of the marginalized groups within formal and informal governance structures processes through mass movement and strategic identification of opportunities within unfolding processes.

Power relations could be referred to interaction between actors (Spicer, 1997). It is described as something that enables who does what to whom (Rath, 1997). The analysis of power relations among CBWP actors, adopted two facets of power relation, that is, power over and power. Power over refers to a conventional supremacy model where decision making is characterized by control, instrumentalism, and self-interest (Berger, 2005). The way global, national and local actors interact in the CBWP is influenced by this variable "power over". Power can also be explained in terms of social reaction. Berger (2005) point out that Power to relations represent forms of resistance that actors may use to try to counter a supremacy model. In this case, actors may resist domination of another powerful actor. For example, the World Bank and IMF laid stringent conditions for Tanzania that, in order to get debt relief the country has to privatize water sector (Goldman, 2005). The Tanzania government accepted such conditions by privatizing water services mainly in Dar es Salaam city. But after a while the government reacted by breaking the contracts with the investors. This shows how actors may react to domination or control of the powerful actor.

\section{Study Methodology}

The study was conducted in two regions of central Tanzania namely, Dodoma and Singida, which were purposively selected to form the study area. The two regions are found in the semi-arid zone characterized by dry-land and poor rainfall, facing a critical shortage of water. The demand for water in these regions is most critical as it impacts agricultural and other productive activities, which is one of the contributing factors to persistent poverty. Failure of water projects might also be due to the persistent poverty in the study area.

The multi stage sampling techniques was employed for selection of the study sample. The starting point was at the region and ending at the community based water projects that resulted into identification of water users and their committees. The technique is convenient for studying large and diverse population (Fowler, 1993). The sampling stages were the regions, districts and finally community based water project.

Two districts from each region were purposively sampled for the study. The selection was based on high projects functionality rate on the one hand and low functionality rate on the other. Kongwa and Kondoa districts were picked from Dodoma region while Manyoni and Singida urban were chosen from Singida. Thirty (30) projects of the CBWP were randomly picked for the purpose of the study. Since there are many CBWP in the study area, 
stratification of the projects basing on similar attributes were done. Three strata were created basing on common extraction methods in the study area. These included gravity extracted projects, engine pump extracted projects and manual extracted projects. Stratification of the projects was done to enable the researcher to study into details different projects available across the study area. A stratified sample of 14 projects from Dodoma and 16 from Singida were taken. The distributions of the projects were as follows; Kongwa (6), Kondoa (8), Manyoni (8) and Singida Urban (8). A total of 390 water users' households and 10 water committees were interviewed.

Analyzing sustainability of community based water projects multiple research methods in two folds were the key approaches in this study. The first approach applied observation and unstructured interviews, and secondly multi-topic household survey by collecting data on various aspects hypothesized to form basis of analyzing sustainability. The application of different methods helps to ensure the quality of the findings by triangulating the findings via comparison of the content of different sources of information (Odell, 2001, Kilonzo, 2008).

\section{Results and Discussion}

\subsection{Analysis of Power Structure at Community Level}

Power is embedded in the relationships that shape how one person or organization has more authority than others (Alsop, 2004), while Jibowo (1992) describes power structure as "patterned distribution of authority and influence among various actors in a group or community". The study presents findings of power structure in the framework of three criteria - Governance, Informality, and empowerment.

\subsubsection{Governance}

Power structure could be analyzed in the way which formal institutions operate in governing the CBWP. The study identified three levels of institutions dealing with CBWP on the surveyed districts; these institutions included top, middle and bottom levels. Top level institutions includes Ministry of water, RALGA and other International Organizations and the Middle level institutions constitutes of the Districts water engineers, and Religious institutions; while at the bottom level there are Village council, Village government, Village water committees and water users. The governance of these institutions tends to differ at all levels. A formal and well organized set of rules guide the top and middle level institutions while at the bottom level there seems to be some loop holes in implementing the rules guiding them, the same findings was documented by Morita-Lou and Waters, (2008) who argued that Local authorities in Tanzania lack strategic oversight to efficiently fulfill their responsibilities. Due to well organization, institutions at the top and middle are very strong and had strong bargaining power, while at the bottom there are weak and loosely institutions (Acemoglu, Johnson, \& Robbinson, 2005). The problem with weak institutions at the bottom end have poor resource management, since the bottom institutions have direct linkage with the projects and are involved in daily management of the projects as supported by Acemoglu, Johnson, \& Robbinson (2005).

For example one common pre-requisite of an autonomous water committee is the need to have independent bank account from the village account. However, the results revealed that weakness of the committees in some villages, paved a way for water committee to use the bank account that is associated with the village account. An interview with a chairperson on one of the water committees in Singida, had commented as follows:

We had our own bank account, but the village government decided to close it and forced us to use the existing village bank account.

The decision of village government rests on the assumption of increasing their revenues at the expense of risking their village water project projects. After confiscating the bank account, the community refused to pay for water and currently water is for free without O\&M fund. These findings concur with Hysom (2006) in a study on factors affecting sustainability of RWS; in his paper, he argued that the village government subvert the operation of the Private Operator in order to regain access to the water revenue.

In other cases the local institutions failed to enforce by-laws and regulations they have set in relation to managing the CBWP. This was observed in one of the CBWP where people used to take their livestock to the project premises where there is no livestock drinking channel. This resulted into the ruining the project facilities, and there was no interventions from the responsible institutions. It could be argued that good governance of the formal and informal institutions is a key ingredient to sustainability of the CBWP, Jonathan Fox cited by Alsop (2004) uses four examples of rural development programs in Mexico to show that programs are most successful where social organizations have the capacity and willingness to participate, and where functions within formal implementing agencies (both at the top and middle levels) are willing to take risks in partnering with social organizations. 


\subsubsection{Informality}

Power structure at both regions (Dodoma and Singida) was analyzed in terms of relationship and linkages that exists between formal and informal institution and the networks that exists at the two areas. The interaction between informal institutions and formal institutions is largely about power and processes by which, it is distributed and exercised. The growing of informal institutions in the study area and the increased linkage with formal institutions brings decision making closer to the local community. The results from the study indicate that availability of informal institutions in the study area, and a close linkage with formal institutions. It has been shown that $70.6 \%$ of respondents agreed that there is a good linkage with formal institutions, when it comes to water project in both Singida and Dodoma regions where we conducted the study. Table 1 presents the field responses on the linkages.

Table 1. Formal and informal institutions linkage in water projects

\begin{tabular}{llcc}
\hline & & Frequency & Valid Percent \\
\hline Linkage & Yes & 269 & 70.6 \\
& No & 112 & 29.4 \\
& Total & 381 & 100.0 \\
\hline
\end{tabular}

Involvement of local communities in their informal institutions and networks increases the chance of local actors to participate in development activities, of which water projects is one of them. CASSAD (1994) argues that:

"For development to occur there is need for a greater participation of local people in development process which will change the nature and direction of development intervention as well as result in a type of development which will have local people's support and recognition."

The study shows significant correlation $(\mathrm{P}=0.009)$ between interaction of informal and formal institutions and sustainability status of projects in the study area. These findings imply that the interactions bring about good patron-client relationship and the odds of getting information and assistance with relation to management of the CBWP becomes much higher.

\subsubsection{Empowerment}

The approach of empowerment in this case focuses on how to increase power of the disadvantaged groups in formal and informal governance structure and processes. With respect to empowerment the study revealed initiatives of the government to include women in the decision making bodies related to CBWP at village level. Global actors have influenced inclusion of women in water users committees, for example World Bank has a policy stating that around $30 \%$ of the local user-committees have to be female. This has been directly adopted with other actors such as the national and local actors. It was revealed during the survey that almost all VWC have a special inclusion of women in their committees. About $90.7 \%$ respondents in both Dodoma and Singida admitted that they have special representations of women and other special groups in their committees. Table 2 presents responses on women and special group representations in various committees including water committees.

Table 2. Special representation of women and other special groups in Dodoma and Singida regions

\begin{tabular}{llcc}
\hline & & Frequency & $\%$ \\
\hline Valid & Yes & 353 & 90.7 \\
& No & 36 & 9.3 \\
& Total & 389 & 100.0 \\
\hline
\end{tabular}

The study also revealed a very strong correlation $(\mathrm{P}=0.000)$ between sustainability status and inclusion of special groups in decision making bodies. The study revealed that over $83.6 \%$ of the committees had inclusion of special groups resides in areas with sustainable projects. Table 3 indicate the cross tabulation of sustainability status and inclusion of special groups. These results could be associated with the reasons that incorporating women in the decision making bodies relating to water, increases the chances of sustaining the projects. This is due to the fact 
that in many communities, women and children are the one who suffer in searching for water, that's why they need to have sustainable projects that would yield benefits for a prolonged period of time. Supporting these findings Agarwal, (2000) noted that the inclusion of women will improve the management of collectively owned natural resources because women have high social capital. Support Agarwal, Zwarteveen \& Meizen-Dick, (2001) argue that since women are major users of these goods, their involvement will ensure compliance of the rules and regulation set for proper management of the CBWP.

Table 3. Sustainability Status versus Special Groups Inclusion in Decision Making Bodies

\begin{tabular}{|c|c|c|c|c|c|c|}
\hline & & & \multicolumn{3}{|c|}{$\%$ of Sustainability Status } & \multirow[b]{2}{*}{ Total } \\
\hline & & & $\begin{array}{c}\text { Not } \\
\text { Sustainable }\end{array}$ & $\begin{array}{c}\text { Partially } \\
\text { Sustainable }\end{array}$ & Sustainable & \\
\hline \multirow{4}{*}{$\begin{array}{l}\text { Is there any } \\
\text { special } \\
\text { inclusion of } \\
\text { disadvantaged } \\
\text { groups in the } \\
\text { committees? }\end{array}$} & \multirow{2}{*}{ Yes } & $\mathrm{n}$ & 77 & 118 & 51 & 246 \\
\hline & & $\%$ & 55.4 & 63.4 & 83.6 & 63.7 \\
\hline & \multirow[b]{2}{*}{ No } & $\mathrm{n}$ & 62 & 68 & 10 & 140 \\
\hline & & $\%$ & 44.6 & 36.6 & 16.4 & 36.3 \\
\hline \multirow{2}{*}{\multicolumn{2}{|c|}{ Total }} & $\mathrm{N}$ & 139 & 186 & 61 & 386 \\
\hline & & $\%$ & 100.0 & 100.0 & 100.0 & 100.0 \\
\hline
\end{tabular}

** Correlation is significant at the 0.01 level (2-tailed)

\subsection{Power Relations among CBWP Actors}

Power relations involve influencing political structure and processes to change the relative position of the poor (Alsop, 2004). In analyzing power relations among CBWP actors, it was imperative to look on power to effect and the reaction of the effects (power over).

\subsubsection{Actors Power to Effect the CBWP}

Power connotes ability of a group of actors to have ability to influence or capacity to affect the project activities. The question posed at this point should be how do actors effect/exercise power? In answering such a question the study looked on the effects of actors on the projects. It has been shown that global and national actors have power to effect the execution of the projects at higher level. Global actors have an effect in deciding, which projects to fund or not basing on their criteria whilst National actors exercise their power to determine where in the country the project should be implemented, and the type of technology.

The other question that could be asked is where do these actors get their powers? Systematic analysis shows that global actors yield their power from the good financial position while national actors have legitimate power as a result of processes of election or appointment that the society had trust in the whole system. This statement could be justified by looking at the projects implemented at the central Tanzania, the study identifies $80 \%$ of the projects are funded by the global actors while only $20 \%$ are funded by other actors specifically the local actors. Figure 1 indicates water projects' donors. 


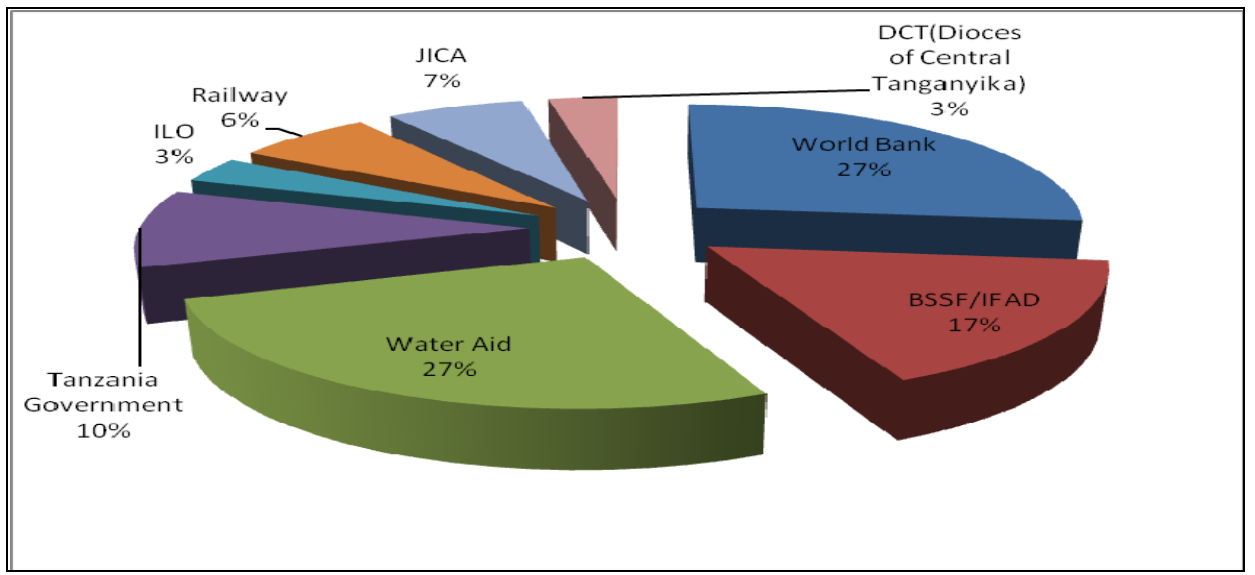

Figure 1. Project Donors in the study area

The powerlessness group of actors is local actors, with fewer opportunities to make choices of the project parameters such as the design and type of technology to be used on the project. The findings conform with that of Kaliba (2002), who showed that majority of respondents in his study about sustainability of CBW and Sanitation Programs were not involved in the choice of technology and choice of water sources.

Analytically, the local actors are not homogenous, there are some groups that have power to effect the project implementation activities, these constitutes of the minority elites in the villages, they form the decision making bodies with respect to the CBWP. These governing bodies have legitimate power because communities accept them as justified and valid, and they are seen as guardians due to the positions they occupy through elections or appointments. The study noted that being well off in terms of wealth increases a chance of being selected in decision making committees, supporting the argument Wall et al., (2005) argues that the socio-economic status of people often limits their access to the decision-making process, excluding them from community affairs. The study find a strong correlation $(\mathrm{P}=0.041)$ between wealth category and being a member of any decision making committee in the surveyed area. Meaning that being well-off in the local community increases the chance of being included in any of the decision making committees in villages. These committees are responsible for big decisions in management of the CBWP and they have significant effect in the sustainability of the projects. The study shows that presence of active water committees have statistical significant influence $(\mathrm{P}=0.01)$ to the sustainability of the CBWP. This statement could justify the fact that power to influence had significant effect on sustainability of the CBWP in the study area.

Another case in relation to power to influence the CBWP governance is build capacity of the local actors. Alsop (2004) stresses that:

"Capacity-building efforts, which emphasize power to, view power as an infinitely expanding resource, talk of capacity building in relation to increasing the community to have capacity to expand resources and power to control their resources."

It is expected that if the global and national actors wants to increase the capacity of the local actors to expand and manage well their resources, capacity building is inevitable. But the study reveals that capacity building is almost negligible to the local actors. Only $12 \%$ had ever attended any training related to water resource management. Figure 2 shows the trend of capacity building to the local community. The capacity building trend jeopardizes sustainability of the CBWP in the study areas. 


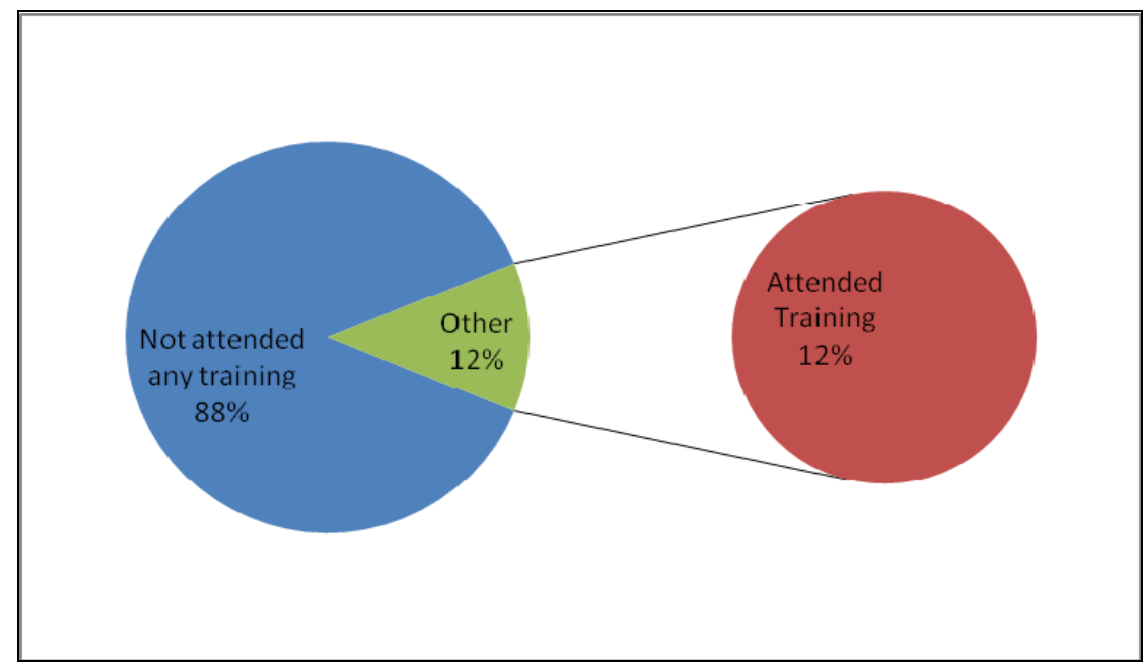

Figure 2. Capacity building in water projects management at the study area

\subsubsection{Actors Reaction to Power Wielding (Power Over)}

Power can also be explained in terms of relational and social action, in some other cases the group of the powerlessness resists exercise of power from the powerful actors, and their resistance might be in many forms. The study reveals some social movements in the fields when water users impeach CBWP governing bodies' as a counter measure to their power wielding. Supporting these arguments in one of the FGD conducted, one of the villagers commented that:

"We have impeached the outgoing village water committee because they were raising water bills whenever they need without our concern, which was very unfair, so we had to do what we did."

In the analysis of power over, Alsop (2004) argues that:

"The counter to power to effect is a struggle for resources, seeking power over, which is pursued by activist groups and social movements..."

As it has been seen in this study such resistance to exercise power does not remove the premises that make the exercise possible, therefore such act of exercising and resisting will continue for quite a long time unless there is power sharing over the CBWP management that will create a win-win solution for the communities.

\subsection{What Do Power Relations Have to Do with Sustainability of CBWP?}

Exercise of power from one actor to the other may limit participation of the inferior actor in the process of development. As it has been shown that the local actors who are perceived to be powerlessness may react to the power exercised by global and national actors, the result would be unsustainable project. Therefore it is important to recognize the central role that power relations play in implementation of CBWP in the study area. The study has shown the way global and national actors exercise power (power to) and the mass reaction from local actors. Analytically the study draws conclusion that power relations affect sustainability of the CBWP in the study area. It is therefore worth for global and national actors to give freedom of choice and encourage local networks, strengthen capacity building to local actors so as to increase the chances of community participation in their development and creating more sense of ownership of the designed projects which will automatically enhance sustainability of the CBWP.

\section{Conclusions and Recommendations}

Power relations of actors in the study area have been explored. In doing so, two basic approaches have been used; power structure and power relations. In examining the power structure it has been shown that the existence and relationship between informal and formal institutions have significant correlation with sustainability status of the surveyed projects, the study also reveals that formal institutions in the study area could be categorized into three levels, i) top ii) middle and iii) bottom, whereby it was noted that the top and middle levels institutions are strong and have bargaining power while the bottom institutions are characterized by weak and lose connections. Power structure was also analyzed in terms of empowerment of disadvantaged group, the study shows strong correlation between empowerment and sustainability of the CBWP which was much associated with the fact that 
women participation in decision making bodies will improve the management of collectively owned projects because they are the major users of the services. Power relation was presented at the perspective of power to effect and power over. The study shows that global and national actors have high influence/power to affect the CBWP critical activities. The local actors are perceived to powerless however the study indicates importance of recognizing them because their position as powerless actors may limit their participation in the CBWP and thus jeopardizing the chances of yielding sustainable CBWP.

\section{Acknowledgement}

Authors of this article acknowledge the University of Dodoma (UDOM)-Tanzania for the supporting environment to conduct this study.

\section{References}

Acemoglu, D., Johnson, S., \& Robinson, J. (2005). Institutions as a Fundamental Cause of Long-Run Growth. Handbook of Economic Growth 1A: 386-472. https://doi.org/10.1080/08913810902933788

Alsop, E. (2004). Power, Rights, and Poverty: Concepts and Connections (eds.), A working meeting sponsored by DFID and the World Bank. https://doi.org/10.1016/j.ejpoleco.2012.07.002

Fowler, F. J. Jr. (1993). Survey Research Methods (2nd ed.). SAGE Publications, Inc. California. https://doi.org/10.1177/0002764293036004003

Goldman, M. (2005). Imperial Nature. Yale University Press, New Heaven and London. https://doi.org/10.1111/j.1468-2427.2010.01001

Harvey, P. A., \& Reed, R. A. (2004). Rural Water Supply in Africa: Building Blocks for International Conference on Water and Environment (Dublin, 1992). The Dublin Statement on Water and Sustainable Development https://doi.org/10.1002/2014WR016770

Haysom, A. (2006). A Study of the Factors Affecting Sustainability of Rural Water Supplies in Tanzania. Cranfield University Masters Dissertation. https://doi.org/10.3362/1756-3488.16-00022

Jibowo, A. A. (1992). Essentials of Rural Sociology. Gbemi Shodipo Press Ltd., Abeokuta, Nigeria. https://doi.org/10.12691/wjar-1-1-4

Kaliba, A. (2002). Participatory Evaluation Of Community-Based Water And Sanitation Programs: The Case Of Central Tanzania, Unpublished PhD thesis. Kansas State University

Kamanzi, A. (2007). Our way: Responding to the Dutch aid in the District Rural Development Program of Bukoba. Tanzania, Leiden: ASC.

Kilonzo, R. G. (2017). This is my Grand Pa's Land: Land, Development Projects and Evictions along Morogoro Highway, Tanzania. Journal of Sustainable Development, 10(2), 37-44. https://doi.org/10.5539/jsd.v10n2p37

Khwaja, A. I. (2001). Can good projects succeed in bad communities? Collective action in the Himalayas. mimeo, Harvard University. https://doi.org/10.2139/ssrn.295571

Kilonzo, R. (2008). Land Conflict in Sub-Saharan Africa: Development and Evictions along the Morogoro Highway, Tanzania. PhD thesis, University of Minnesota, USA.

Kleemeier, E. (2000). The Impact of Participation on Sustainability: An Analysis of the Malawi Rural Piped

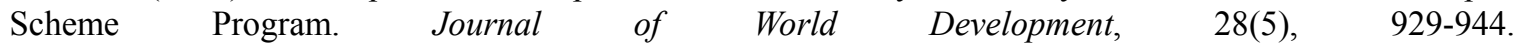
https://doi.org/10.1016/S0305-750X(99)00155-2

Long, N. (2004). Actors, interfaces and development intervention: meanings, purposes and powers. In Kontinen, T. (Ed.), Development intervention: Actor and Activity perspectives. University of Helsinki.

UNICEF and WHO. (2005). Water for Life report. https://doi.org/10.18820/9781920338374

Zwarteveen, M., \& Meizen-Dick, R. (2001). Gender and Property-Rights in the Commons: Examples of Water Rights in South Asia. Journal of Agriculture and Human Values, 18(2), 11-25. https://doi.org/10.1016/B978-0-12-375678-7.00212-1483

\section{Copyrights}

Copyright for this article is retained by the author(s), with first publication rights granted to the journal.

This is an open-access article distributed under the terms and conditions of the Creative Commons Attribution license (http://creativecommons.org/licenses/by/4.0/). 